\title{
Performance and emission comparison of Karanja (pongamia pinnata), Pithraj (aphanamixis polystachya), Neem (azadira chtaindica) and Mahua (madhuca longofolia) seed oil as a potential feedstock for biodiesel production in Bangladesh
}

\author{
N. Hoque ${ }^{1 *}$, M. Mourshed ${ }^{1}$ and B.K. Das ${ }^{1}$ \\ ${ }^{1}$ Department of Mechanical Engineering \\ Rajshahi University of Engineering \& Technology, Rajshahi-6204 \\ *Email: shumon99234@gmail.com, \\ Phone: +8801716591872
}

\begin{abstract}
This paper investigates the production of biodiesel (BD) from karanja (Pongamia pinnata), pithraj (Aphanamixis polystachya), neem (Azadira chtaindica) and mahua (Madhuca longofolia) seed oil through acid esterification, followed by the investigation on the transesterification process and physicochemical properties of oils. This study also includes their effects on engine performance and emission on a direct ignition (DI) diesel engine. A maximum 9 of $6 \%$ by volume methyl ester (biodiesel) was obtained from mahua oil at methanol concentration of $22 \mathrm{vol} \%$, catalyst concentration of $0.5 \mathrm{wt} \%$ and a temperature of $55^{\circ} \mathrm{C}$ and at the same condition $94 \%, 92 \%$ and $91 \%$ biodiesel extraction was experienced for neem, pithraj and karanja seed oil respectively. The diesel-biodiesel blend (B10) has been used during the test run and it was found that all of the fuels showed performance closer to the neat diesel. Among all the biodiesels, karanja showed better performance compared to the other three. On the other hand, high oxygen content of biodiesel causes less $\mathrm{CO}$ and $\mathrm{NO}_{\mathrm{x}}$ emission. It was experimentally found that mahua emits the least amount of $\mathrm{CO}$ and $\mathrm{NO}_{\mathrm{x}}$ which were $44.44 \%$ and $38.3 \%$ respectively compared to the neat diesel. Results indicate that these oils are potential biodiesel feedstock and can be used as an alternative to the diesel fuel in the near future. Desirable engine performance and tail pipe emissions are also observed during the experimental investigation.
\end{abstract}

Keywords: Alternative fuel; biodiesel; inedible sources; DI diesel engine; performance and emissions.

\section{INTRODUCTION}

Rapid depletion of fossil fuels and strict emission regulations strongly forced researchers to explore renewable sources of energy. Biodiesel is one of the promising renewable energy options already exploited by researchers in different countries [1-4]. Different categories of feed stocks as sources of suitable oil for biodiesel production include seeds, nuts, leaves, wood, and even bark of trees. At present, the world is highly dependent on petroleum fuels for generating power, vehicle movement, agriculture and domestic useable machinery operation and for running the different industries [5]. With technological progress and improvement of living standard of the people, the demand of the petroleum fuel increases simultaneously. But the reserve of the petroleum fuels are so evenly distributed that many regions have to depend on others for their fuel requirements. The price of the petroleum is also increasing day by day and the use of the petroleum fuel in engine produces harmful products which pollute the environment [5]. Due to the above 
reasons, attention has gone to the search of renewable source of fuel which can meet the demand. Bangladesh has good potential of various edible and non-edible oils and locally available vegetable oils may be an alternative source of diesel fuel, which can be produced in any local area [6].

Plant vegetable oils can be used as alternative fuels for diesel engine. Due to higher viscosity, lower volatility, carbon deposits and oil ring sticking, their direct uses are limited to diesel engine [7]. There are several techniques to reduce the viscosity of vegetable oils. The techniques are dilution, pyrolysis, micro emulsion and transesterification [8]. Like vegetable oils, it is well-known that biodiesel is also an alternative fuel and can be derived from straight vegetable oils (edible or inedible), animal fats, waste cooking oils or even from yellow grease through a process known as transesterification [9]. The production of biodiesel involves chemically reacting a vegetable oil or animal fat with an alcohol such as methanol. The reaction requires a catalyst, usually a strong base, such as sodium or potassium hydroxide, and produces new chemical compounds called methyl esters, which is known as biodiesel. Most studies suggest that engine power is reduced with the biodiesel as biodiesel has low heating value compared to diesel [10-13]. Factors which affect the engine power are content of biodiesel, properties of biodiesel and its feedstock, engine type and its operating conditions and additives. Proper optimization of injection timing, injection pressure and proper improvement of additives can solve this problem to a great extent. Moreover, when biodiesel is used as blend with diesel it is difficult to perceive this problem. Fazal et al. [14] reported that vegetable oils have acceptable cetane numbers (35-45), high viscosity $(50 \mathrm{Cst})$, high flash points $\left(220-285^{\circ} \mathrm{C}\right)$ and high pour points $\left(-6\right.$ to $\left.12^{\circ} \mathrm{C}\right)$ as well as substantial heating values (about $90 \%$ of diesel) and low sulfur content $(<0.02 \%)$. They also studied the properties of different vegetable oils and modified fuels for automotive application. Biodiesel has ability to reduce emission and the smoke density when fueling biodiesel of Soybean oil [15].

The use of biodiesel reduces the engine power and increases fuel consumption due to its low heating value. But when biodiesel is used as blend with diesel, these problems are greatly minimized. Majority of researchers says that NOx emission increases with biodiesel. It is because of the higher oxygen content in the biodiesel [16]. Researchers suggest that this problem can be greatly minimized with adjustable amount of EGR and manipulation of operating condition, mainly injection timing [17-21]. It is almost proven that $\mathrm{CO}$ and $\mathrm{HC}$ emission reduces with biodiesel because of its high oxygen and lower carbon to hydrogen ratio compared to diesel. Biodiesel reduces huge amounts of $\mathrm{CO}_{2}$ from the view of life cycle analysis of $\mathrm{CO}_{2}$. J. Xue et al. (2011) [5] reported that biodiesel will cause $50-80 \%$ reduction in $\mathrm{CO}_{2}$ emissions compared to petroleum diesel. The purposes of this study are to produce biodiesel from renewable sources of energy named pithraj oil, karanja oil, neem oil and mahua oil and to investigate the engine performance and exhaust emissions with these biodiesel blends (B10). The subsequent section explains the materials and methods involved in the study, while the comparison of neat diesel and the biodiesel under consideration is given in the third section. The performance of different biodiesels is listed as results and discussions in section four.

\section{MATERIALS AND METHODS}

Bangladesh imports around $90 \%$ of its petroleum from foreign countries. In this case, vegetable oils can play a vital role to meet the rapid increase in demand for petroleum for a developing country like Bangladesh. The study includes four promising seed oils which 
were collected locally from Rajshahi Division of Bangladesh. As of today, commercial production of biodiesel does not exist in Bangladesh though the agro-climatic conditions are favorable for the cultivation of these plants. The considered four seeds can be grown in low fertility fallow lands, hilly lands and also survive in low rainfall while having considerable amount of oil content compared to others. Moreover, these biodiesels can be prepared in economical ways. Nabi et al. (2009) [22] reported that by planting jatropha curcas, Bangladesh can reduce importing a huge amount $(25 \%)$ of petroleum products from foreign countries and planting pithraj can also save $21 \%$ of petroleum products. Figure 1 shows the seeds of the plants.

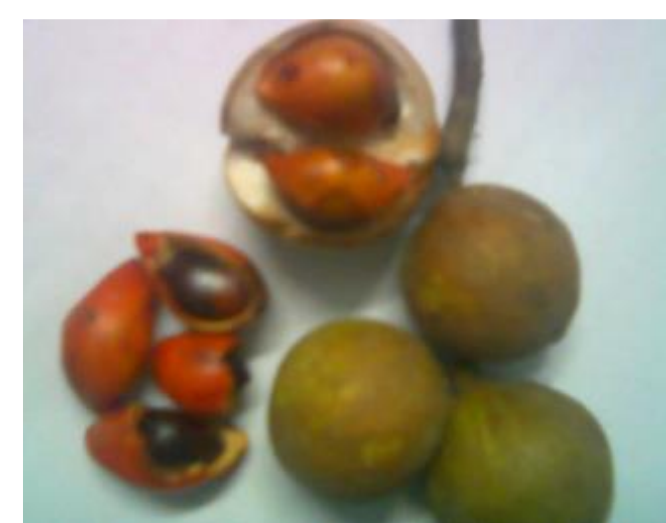

Pithraj (Aphanamixis polystachya)

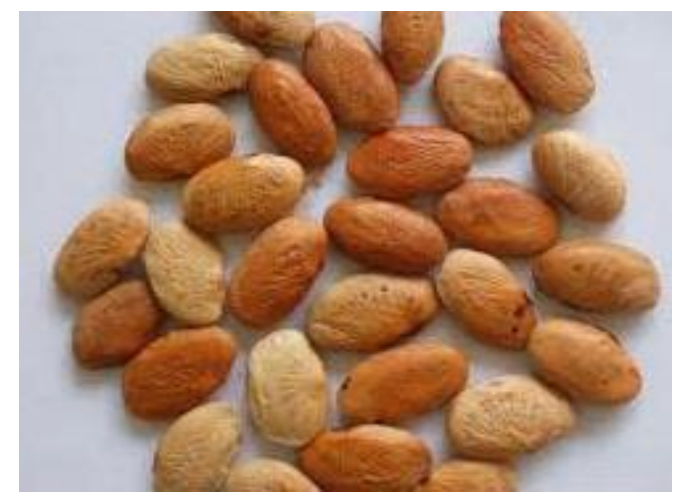

Karanja ( Pongamia pinnata)

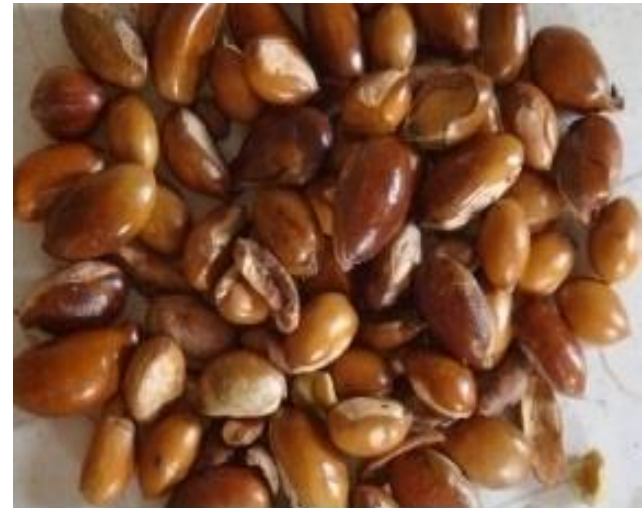

Mahua (Madhuca longofolia)

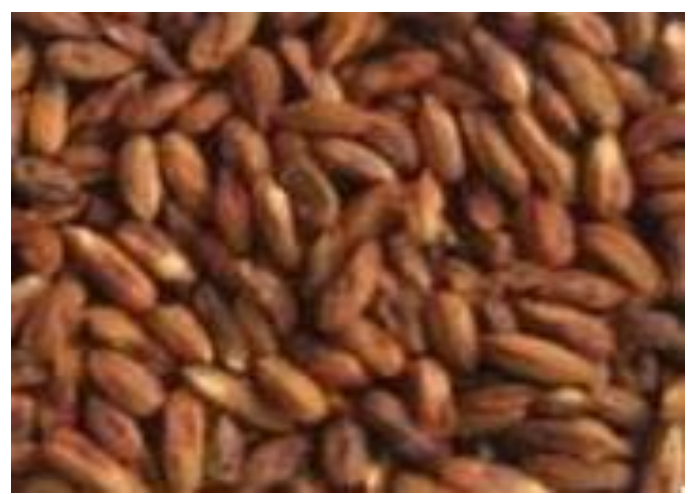

Neem (Azadira chtaindica)

Figure1. Seeds of Pithraj, Karanja, Neem and Mahua.

The most important parameters relevant to biodiesel production are the free fatty acids (FFA) content and moisture content. The FFA content of vegetable oil will vary and depends on the quality of the feed stock [23]. During alkali catalyst based transesterification, the higher the FFA content of the oil, the more alkali is needed to neutralize the FFA and it leads to soap formation and the separation of products becomes difficult and as a consequence, low yields of biodiesel are produced [9]. Acid esterification are advantageous for oils having high FFA, as acid catalyzes the FFA esterification to produce fatty acid methyl ester (FAME), thus increasing the biodiesel yield, but reaction time and alcohol requirement are substantially higher than those of base catalyzed transesterification [8, 9]. In this study, biodiesel (BD) from karanja (Pongamia pinnata), pithraj (Aphanamixis polystachya), neem (Azadira chtaindica) and 
mahua (Madhuca longofolia) seed oil was produced by acid esterification followed by transesterification process due to high FFA concentration in these vegetable oils feedstock. For acid esterification, $\mathrm{H}_{2} \mathrm{SO}_{4}$ was used as catalyst while methanol and $\mathrm{NaOH}$ were used as base catalysts for the transesterification process.

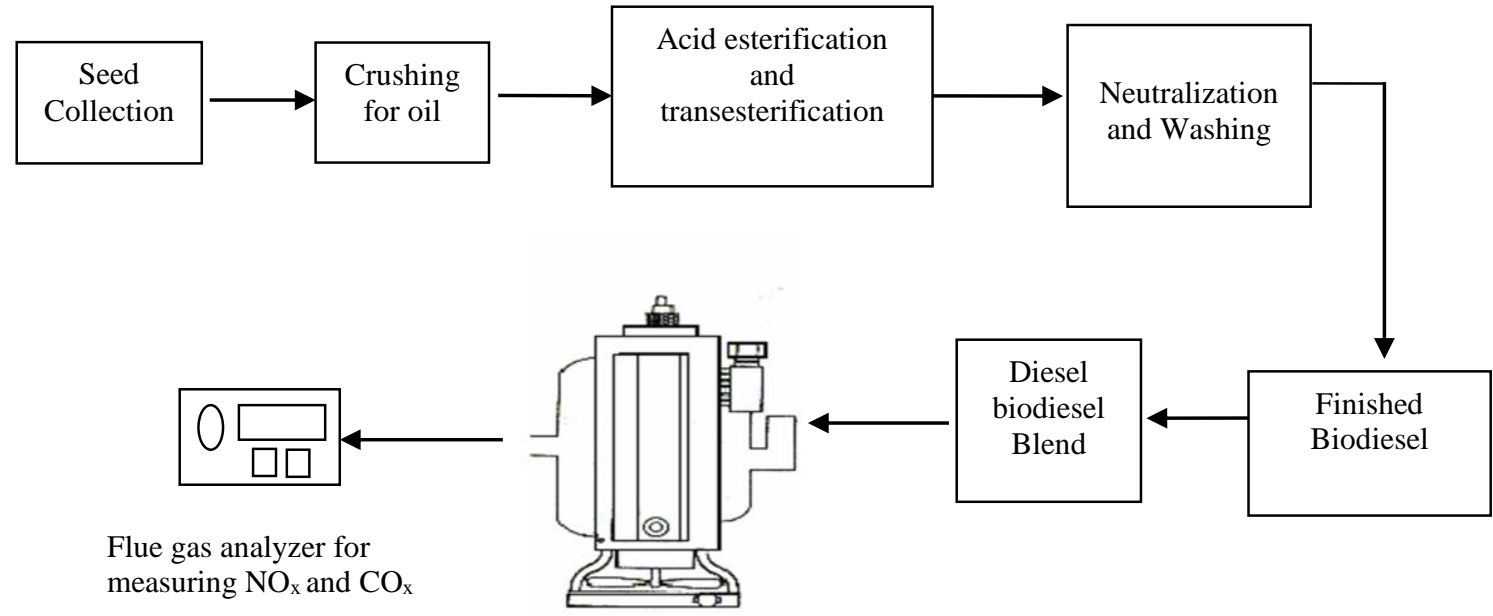

Tested 4-stroke DI diesel engine

Figure 2. Schematic diagram of the experimental setup.

The experimental setup is shown in Figure 2. Firstly, the vegetable oils were filtered and pre-processed to remove water and contaminants, and then fed to the acid esterification process. For acid pretreatment, the oils were taken to the rounded flask where $\mathrm{CH}_{3} \mathrm{OH}$ and $1 \% \mathrm{H}_{2} \mathrm{SO}_{4}$ were added to the flask and heated continuously for an hour $[7,8]$. During heating and stirring the mixture, acid value and FFA concentration were tested. When the FFA concentration was less than $1 \%$, the alkalized transesterification was then conducted with pre-treatment vegetables oil. In this process, different parameters including catalyst to oil ratio (w/w), $\mathrm{CH}_{3} \mathrm{OH}$ to oil ratio (w/w), and the reaction temperature were investigated. The acid value was found to be less than $2 \%$ and the FFA concentration was less than $1 \%$ at a methanol to oil ratio of $55 \mathrm{wt} . \%$. It was also observed that the maximum biodiesel production, the volumetric percentage of $\mathrm{CH}_{3} \mathrm{OH}$ was kept constant at $22 \%$ and temperature was varied from $40^{\circ} \mathrm{C}$ to $55^{\circ} \mathrm{C}$ and the weight percentage of catalyst was kept at $0.5 \%$ [7-9].

The experimental study was conducted by using a single cylinder water-cooled, naturally aspirated (NA) 4-stroke DI diesel engine. The specifications of the engine are shown in Table 1 . The flow rate of the fuel was measured by timing with a stop watch the consumption for known quantity of fuel (10cc) from a burette. The speed was measured directly from the tachometer attached with the dynamometer. The engine torque was measured by using rope brake dynamometer, which is coupled to the engine. The cooling water outlet and exhaust gas temperature were measured directly from the thermometer attached to the corresponding passages. An inclined water tube manometer connected to the air box (drum) was used to measure the air pressure. A high pressure mechanical fuel pump and a printle type fuel injector with a nozzle hole (nozzle diameter $0.25 \mathrm{~mm}$ ) were used in the injection system. The fuel injection time was set at $24^{\circ}$ BTDC. Initially, the engine was run by the diesel fuel for about 30 minutes to warm up and bring to stable condition. In that situation, emission and exit line temperature was uniform and it was 
ensured to be constant for every observation to evaluate performance. At first, the experimental data was taken for diesel and then for $90 \%$ diesel and $10 \%$ pithraj, karanja, neem and mahua biodiesel oil.

Table 1. Engine specification.

\begin{tabular}{ll}
\hline Engine type & 4-stroke DI diesel engine \\
\hline & \\
Engine no. & $4062 \mathrm{AVI}$ \\
Number of cylinders & One \\
Bore $\times$ stroke & $80 \times 110 \mathrm{~mm}$ \\
Swept volume & $553 \mathrm{cc}$ \\
Compression ratio & $16.5: 1$ \\
Rated power & $4.476 \mathrm{~kW}$ at $1800 \mathrm{rpm}$ \\
Types of fuel pump & High pressure, mechanical type \\
Fuel injection pressure & $14 \mathrm{MPa}$ (at low speed,900 to $1000 \mathrm{rpm})$ \\
& $20 \mathrm{MPa}($ at high speed, 1100 to $1800 \mathrm{rpm})$ \\
Fuel injection timing & $24{ }^{\circ} \mathrm{BTDC}$ \\
\hline
\end{tabular}

A portable digital gas analyzer (IMR 1400) was used to measure the exhaust gas emission like CO and NOx. The detail specification of the IMR 1400 gas analyzer was given at Table 2. The engine was running at different speeds ranging from 900 to 1400 rpm and then $1200 \mathrm{rpm}$ was selected on the basis of maximum thermal efficiency. All the experimental data were taken for three times and the mean was used by running the engine at $1200 \mathrm{rpm}$ and under different load conditions.

Table 2. Gas analyzer (IMR 1400) specification.

\begin{tabular}{|c|c|c|}
\hline Parameter/principle & Range/resolution & Accuracy \\
\hline $\mathrm{O}_{2}$ oxygen & $0-20.9 \%$ & $\pm 0.2 \%$ \\
\hline Electrochem sensor & 0.1 vol. $\%$ & \\
\hline $\begin{array}{l}\text { CO carbon monoxide electrochem } \\
\text { sensor }\end{array}$ & 0-2000/4000 ppm & $\mathrm{Z}$ \\
\hline $\mathrm{H}_{2}$ compensated & & \\
\hline $\mathrm{CO}_{2}$ carbon dioxide calculated & $\begin{array}{l}0-\mathrm{CO}_{2} \max \\
0.1 \text { vol. } \%\end{array}$ & $\pm 0.2 \%$ \\
\hline CO nitric oxide electrochem. Sensor & 0-2000 ppm $\square \square \square$ & $\mathrm{Z}$ \\
\hline Draft draft/pressure pressure sensor & $\begin{array}{l}-60 \ldots \ldots \ldots \ldots .+60 \mathrm{hPa} \\
0.01 \mathrm{hPa} / 0.1 \mathrm{hPa}\end{array}$ & $2 \%$ \\
\hline T-GA gas temperature thermocouple & $-20{ }^{\circ} \mathrm{C} \ldots \ldots \ldots+1200{ }^{\circ} \mathrm{C}$ & $1 \%$ v. M./ \\
\hline $\mathrm{NiCrNi}$ & $1^{\circ} \mathrm{C}$ & $\pm 1{ }^{\circ} \mathrm{C}$ \\
\hline $\mathrm{T}-\mathrm{R}$ room temperature thermo sensor & $-20{ }^{\circ} \mathrm{C} \ldots \ldots \ldots+1200^{\circ} \mathrm{C}$ & $\pm 1^{\circ} \mathrm{C}$ \\
\hline Air probe & Integrated current sensor & Air probe \\
\hline Condensate trap & Bulb type manually emptied & Condensate trap \\
\hline
\end{tabular}




\section{COMPARISON OF BIODIESEL PROPERTIES WITH NEAT DIESEL}

The major properties of biodiesel include calorific value, diesel index, flash point, fire point, cloud point, pour point, density, and kinematic viscosity. The various physicochemical properties of diesel and biodiesel produced from pithraj, karanja, neem, and mahua seed are measured and presented in Table 3 for comparison. These properties were determined by following the established standards and compatible with the results concluded by several works $[6,7,22,24,25]$. It can be noted that the calorific value of mahua biodiesel is $17 \%$ less than that of diesel, while pithraj andneem oil has almost same calorific value but is $13 \%$ less than the diesel oil whereas karanja oil has the highest calorific value than that of the other three biodiesels. This might be due to the presence of oxygen atoms in the fuel molecule of biodiesel [26]. The kinematic viscosities of biodiesel are greater than the diesel oil but mahua oil has the viscosity close to diesel oil.

Table 3. Comparison of various biodiesel (B10) properties and diesel oil.

\begin{tabular}{lccccc}
\hline \multicolumn{1}{c}{ Properties } & Neat Diesel & Pithraj oil & Karanja oil & Neem oil & Mahua oil \\
\hline Density $(\mathrm{gm} / \mathrm{cc})$ & 0.86 & 0.948 & 0.9434 & 0.9466 & 0.872 \\
Viscosity $(\mathrm{cSt})$ & 4.98 & 6.22 & 5.86 & 6.05 & 5.2 \\
Higher heating & 44579 & 38588 & 40750 & 38150 & 37000 \\
value $(\mathrm{kJ} / \mathrm{kg})$ & & & & & \\
Fire point $\left({ }^{\circ} \mathrm{C}\right)$ & 90 & 210 & 220 & 228 & 150 \\
Flash point $\left({ }^{\circ} \mathrm{C}\right)$ & 80 & 197 & 210 & 220 & 118 \\
Cetane index & 47 & 51 & 58 & 43 & 52 \\
pH value & 7 & $7.00-7.46$ & $7.58-8.87$ & $4.38-4.92$ & $7.14-7.31$ \\
\hline
\end{tabular}

The higher viscosity of biodiesel could potentially have an impact on the combustion characteristics because high viscosity affects its atomization quality [27]. The flash and fire points of the four seeds biodiesel are much higher than that of diesel, which makes biodiesel safer than diesel from ignition due to accidental fuel spills during handling. Pithraj oil, karanja oil and mahua oil have higher cetane number while neem oil has lower cetane index compared to diesel oil. The density of karanja oil, pithraj oil and neem oil is almost same but greater than mahua oil, which shows almost same value to that of diesel oil.

\section{RESULTS AND DISCUSSION}

\section{Effect of Methanol Percentages on Biodiesel Yield}

The transesterification process was performed to yield biodiesel from the neem, karanja, pithraj and mahua by keeping the catalyst $\mathrm{NaOH}$ concentration constant at $0.5 \%$. From Figure 3, it can be noted that the biodiesel yield was varied with the varying $\mathrm{CH}_{3} \mathrm{OH}$ concentration (ranging from $16 \%$ to $24 \%$ ). The biodiesel yield was increased for all the non-edible seeds with the increase in $\mathrm{CH}_{3} \mathrm{OH}$ concentration up to a maximum nearly about $22 \%$ and then decreased steadily. This fact can be characterized by the increase of $\mathrm{CH}_{3} \mathrm{OH}$ concentration, whereby the rates of complete transformation of oil to biodiesel is increased and after exceeding the optimum $\mathrm{CH}_{3} \mathrm{OH}$ concentration level, it is found difficult to separate bio diesel from the water [28, 29]. 


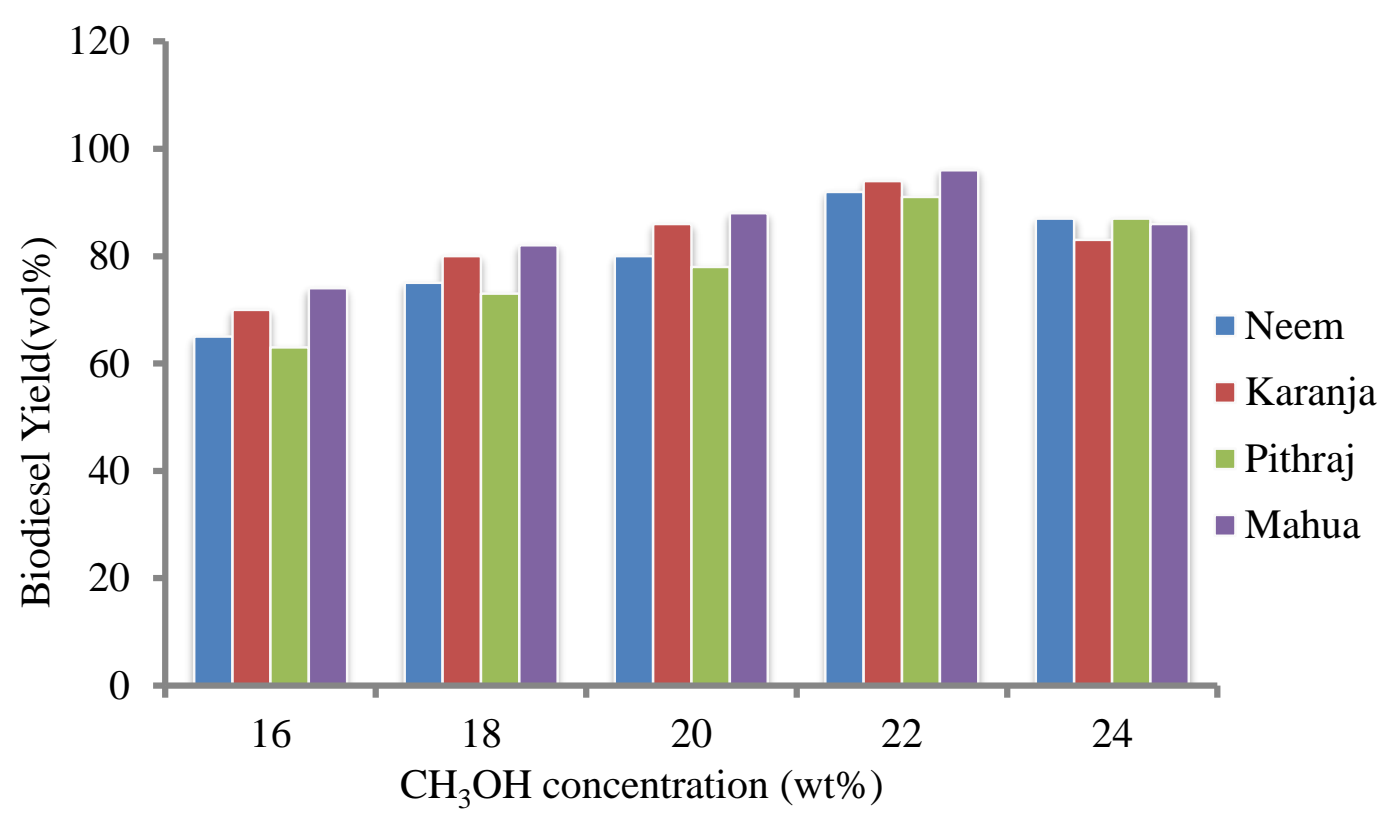

Figure 3. Variation of biodiesel with $\mathrm{CH}_{3} \mathrm{OH} \%$ vol.

However, the emulsification process gets complicated with the increasing $\mathrm{CH}_{3} \mathrm{OH}$ concentration as it has one $\mathrm{OH}$ group that contributes to more $\mathrm{H}_{2} \mathrm{O}$ production. The esterification reaction is presented as:

$$
\mathrm{RCOOH}+\mathrm{CH}_{3} \mathrm{OH}=\mathrm{RCOOCH}_{3}+\mathrm{H}_{2} \mathrm{O}
$$

Also, higher $\mathrm{CH}_{3} \mathrm{OH}$ concentration causes more reaction time with higher density. The maximum biodiesel yield that could be attained for the seeds under consideration was about $22 \%$ of $\mathrm{CH}_{3} \mathrm{OH}$ concentration $(\% \mathrm{wt})$ while the temperature range was varied from $40^{\circ} \mathrm{C}$ to $55^{\circ} \mathrm{C}$. From the experimental data, it is obvious that the maximum biodiesel yield was obtained for the neem seeds due to its physiological properties, which correspond to previous research [7-9].

\section{Effect of $\mathrm{NaOH}$ Percentages on Biodiesel Yield}

With the intention to investigate the effect of catalyst concentration on the biodiesel yield, the experiment was performed. The concentration of the $\mathrm{NaOH}$ catalyst was varied from $0.4 \%$ to $0.55 \%$ by $\%$ of wt. For the optimum biodiesel production, the volumetric percentage of $\mathrm{CH}_{3} \mathrm{OH}$ was kept constant at $22 \%$ and temperature was varied from $40^{\circ} \mathrm{C}$ to $55^{\circ} \mathrm{C}$. Figure 4 illustrates that the biodiesel production increases with the increase in the catalyst concentration until it reaches a value about $0.48 \mathrm{wt} \%$ to $0.5 \mathrm{wt} \%$ and then decreases with a decrease in catalyst concentration. As the catalyst increases up to the maximum value, the biodiesel yield increases, which results in an increase in density and specific gravity $[5,30]$. So, the Pithraj biodiesel has the highest density among the others under consideration and about $96 \mathrm{wt} \%$ is obtainable. This holds well with earlier reports $[6,7]$. However, increasing amount of catalyst causes higher free fatty acids (FFA) and forms more wax and glycerol. Also, higher $\mathrm{NaOH}$ content results in soapinification reaction, which hampers biodiesel production [31]. 


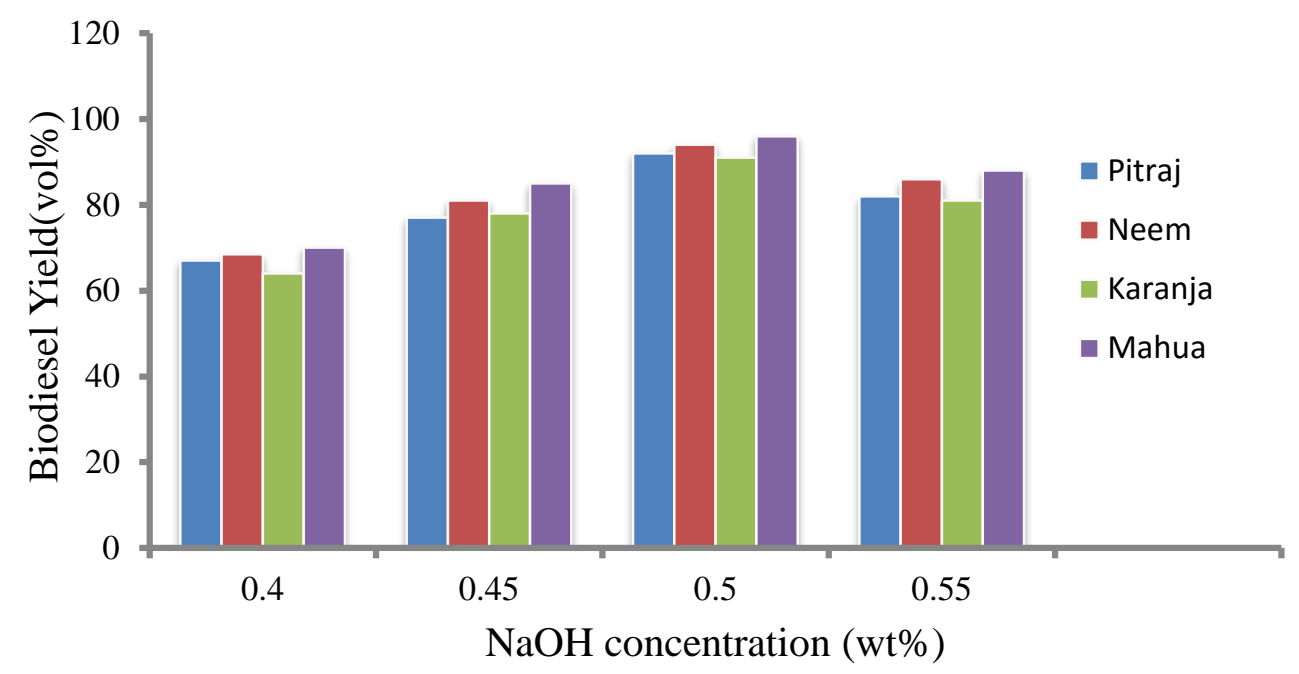

Figure 4. Variation of biodiesel yield with catalyst $(\mathrm{NaOH})$ concentration (temperature $=60^{\circ} \mathrm{C}$ ).

Effect of Reaction Time on Biodiesel Production $\left(\mathrm{CH}_{3} \mathrm{OH}=22 \%, \mathrm{NaOH}=0.5 \%\right)$ Figure 5 illustrates the variation of biodiesel yield through the transesterification process with the reaction time. It is observed that the biodiesel production increases with the reaction and the production level reaches a maximum when the reaction time is near about 15-17 hours. This is because the complete conversion of biodiesel requires sufficient time to accomplish with less wax and other impurities [8,9]. The maximum biodiesel was extracted from the Mahua seeds and it was about $96 \%$ by weight and it had lower density than other biodiesel oils. Afterwards, as the reaction time is increased, the biodiesel yield is decreased gradually and agrees strongly to prior analysis [26]. This fact can be explained due to the formation of wax and other impurities with the increasing reaction time.Also, the methanol gets enough time to evaporate and thus hinders the biodiesel production as the reaction took place without pressurization. It is also noted that the volumetric percentage of $\mathrm{CH}_{3} \mathrm{OH}$ was kept at $22 \%$ and the weight percentage of catalyst was kept at $0.5 \%$.

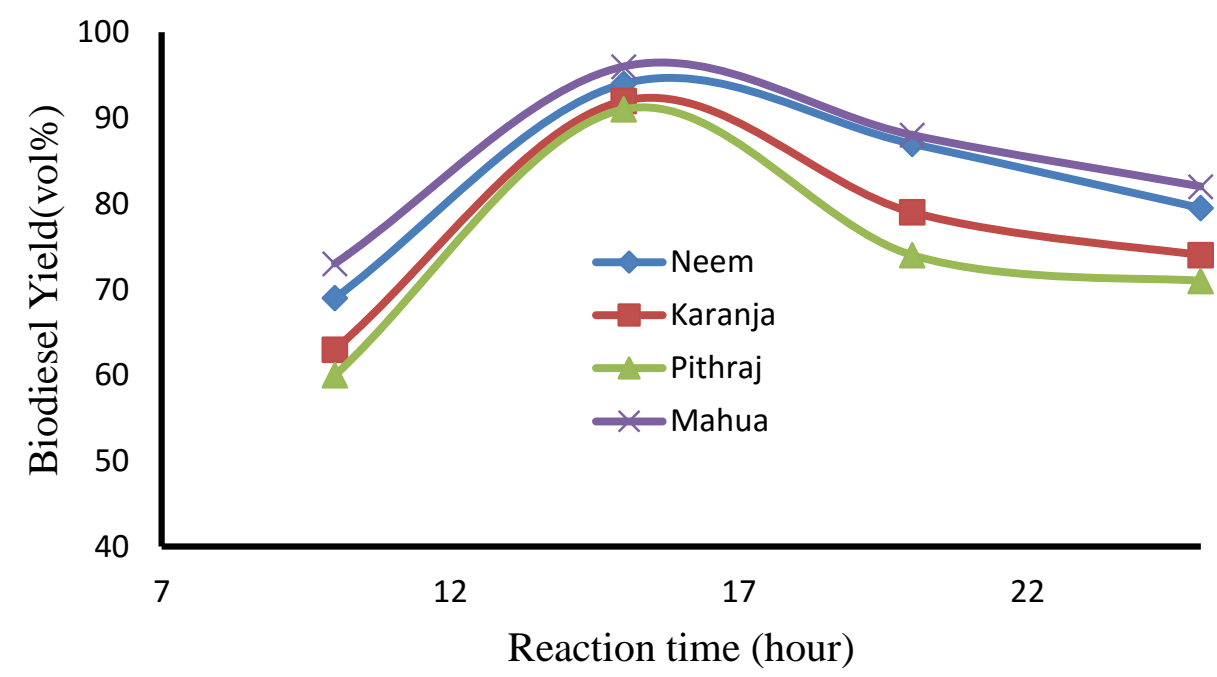

Figure 5. Effect of reaction time on biodiesel production $\left(\mathrm{CH}_{3} \mathrm{OH}=22 \%, \mathrm{NaOH}=\right.$ $0.5 \%)$. 


\section{Performance Study}

The average effective cylinder pressure that does useful work calculated from the engine 'brake horse power (BHP)' is referred to as the "Brake Mean Effective Pressure or BMEP". It is a function of temperature of gases in cylinder. To obtain more heat energy, more fuel needs to be burnt. Meanwhile, torque is a function of BMEP and engine displacement. On the other hand, BHP is a function of engine speed and torque. The ratio of the work done during one complete engine revolution to the engine swept volume, gives the engine BMEP. Thus, BMEP measures the effective work output of the engine $[6,7]$.

$$
B M E P=\frac{2 \pi T N}{V_{S}}
$$

In equation (2), $\mathrm{T}$ refers to torque developed $(\mathrm{N}-\mathrm{m}), \mathrm{N}$ is the number of revolution per cycle $(\mathrm{N}=1$ for two stroke engine and $\mathrm{N}=2$ for four stroke engine), $\mathrm{Vs}$ is the swept volume (m).

The variation of the BSFC with neat diesel fuel and different biodiesel is depicted in Figure 6. BSFC for various biodiesel decreases with the increases in BMEP and reaches it minimum value near BMEP 4 bar. At the initial stage, the BSFC decreases, which may be attributed to the complete combustion of fuel. After a while, the engine reaches the full load level and the time for complete combustion gets reduced and a slight rise in BSFC is observed. This fact can be explained as, the brake power of the engine increases with the load but the time needed for the complete combustion of a certain amount of fuel is increased. Thus, the BSFC decreased after attaining full load.

Karanja oil has the lower BSFC than the other three types of biodiesel and close to diesel oil at BMEP 4 bar. From Figure 6, it is clear for different engine loads that the BSFC is higher for all the biodiesels than neat diesel due to the higher heating value of the diesel fuel and a higher content of oxygen in biodiesel. Also, the viscosity and specific gravity of the biodiesel fuels affects the atomization process as well as the BSFC of the fuel [32, 33].

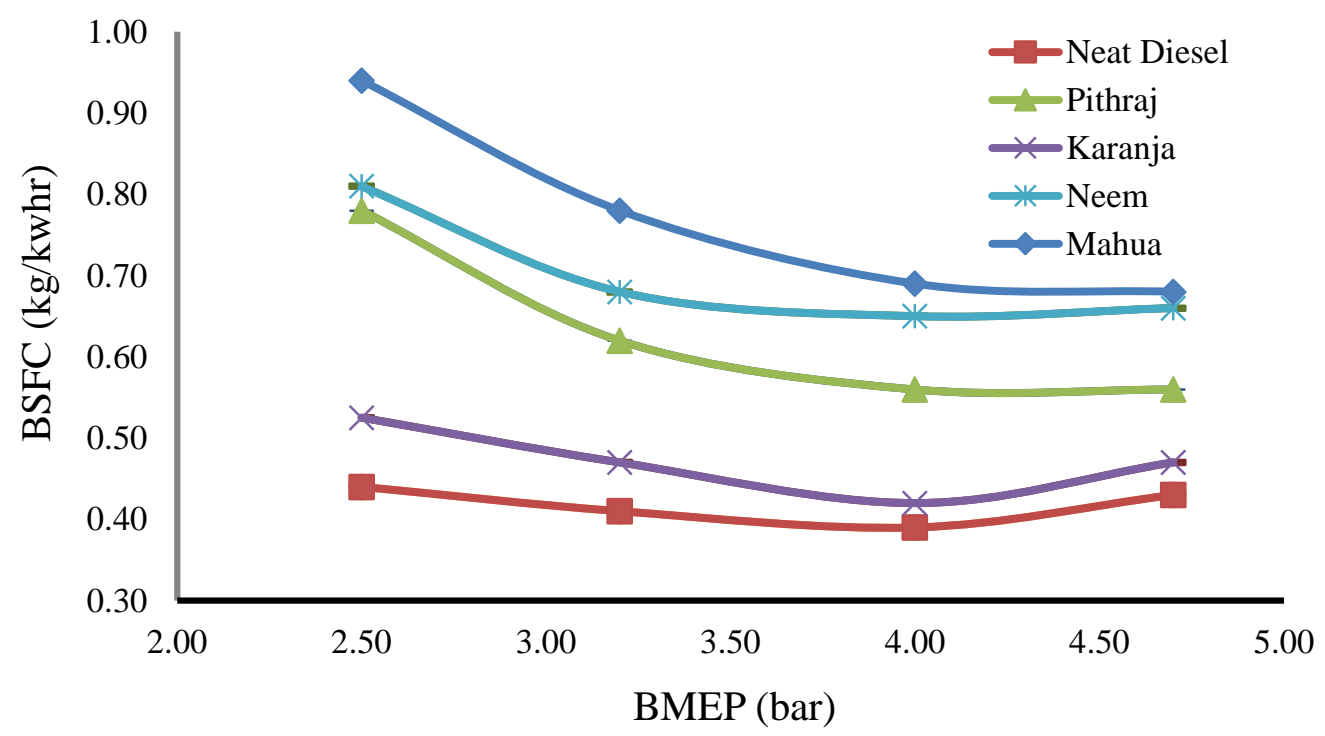

Figure 6. BSFC with different fuels. 
The general trend of the curves in Figure 7 represents that the BP of crank shaft increases with the increase in BMEP up to a certain value (around 4 bars) of BMEP and then decreases. At around 4 bar, the BP for neat diesel is higher than karanja, pithraj, neem and mahua oil by $16.97 \%, 34.55 \%, 38.1 \%$ and $45.45 \%$ respectively. The calorific value of different fuels is an indication to the energy output by the fuel. Thus, neat diesel has the highest energy output among the others. From Figure 7, it is also evident that after reaching the full load condition, incomplete combustion takes place and the energy output for all fuels is decreased, which also confirms the earlier reports on biodiesel fuels [5, 34].

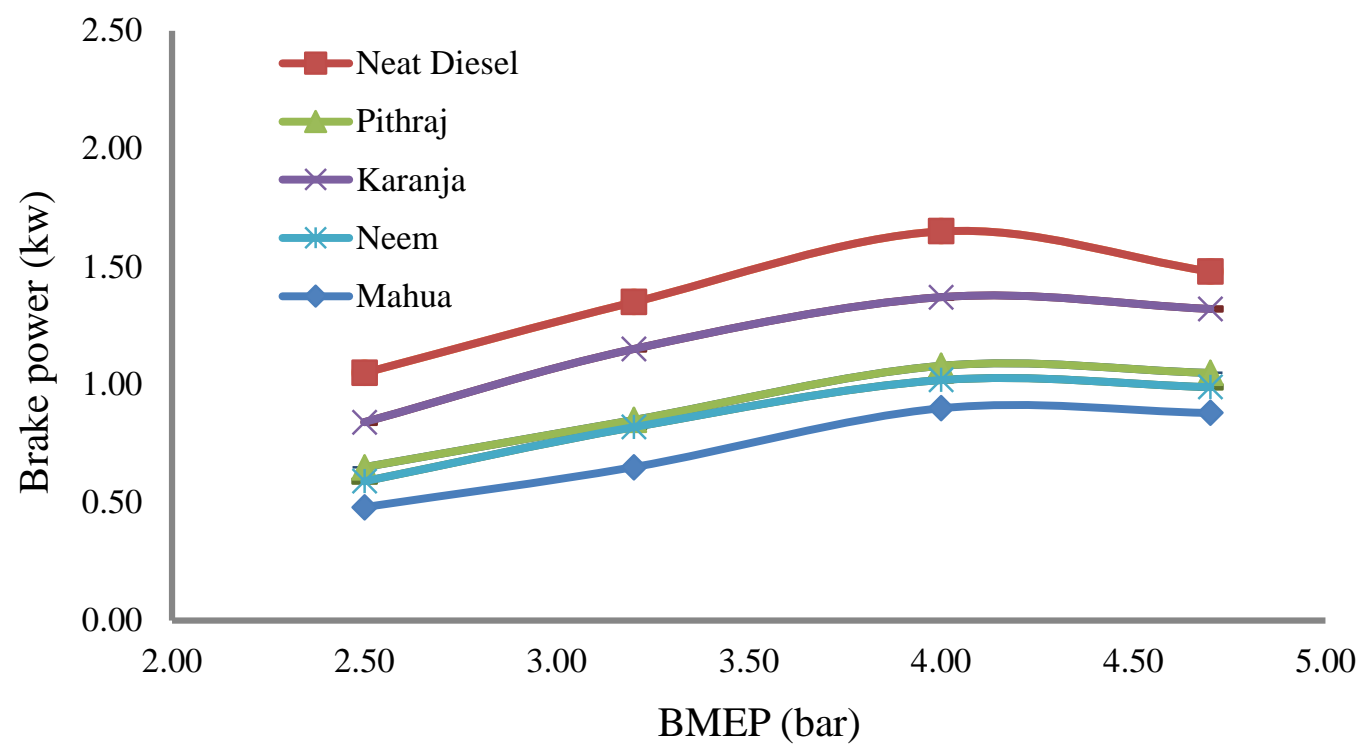

Figure 7. Brake power with neat diesel and various fuels.

The brake thermal energy indicates the proportion of thermal energy extracted by combustion system and transfers the suitable mechanical work to the crank shaft. It can be calculated by the following equation:

$$
\eta_{b}=\frac{B . P \times 3600 \times 100}{m_{f} \times H V}
$$

where, in equation (2), $\eta_{b}$ is the brake thermal efficiency in percentage and $H V$ is heating value of the fuel in $\mathrm{kJ} / \mathrm{kg}$. Also, it is obvious that the $H V$ varies inversely to the $\eta_{b}$.

Figure 8 illustrates the variation of thermal efficiency with BMEP for neat diesel and various biodiesel fuels. The trends of the curves follow an increase in the efficiency with the increase in BMEP up to almost 4 bars and then slightly decreased. The initial increase is due to the proper combustion of the fuel and for biodiesel, excess amount of oxygen contributes to a greater extent. However, after reaching full load, the efficiency is decreased due to incomplete combustion of fuel with a higher BSFC [35]. From the above equation, it is clear that the engine torque increases with the engine load and results in higher thermal efficiency. At higher load, more fuel is injected in the combustion chamber 
and causes incomplete combustion of fuel. Thus, the thermal efficiency is decreased [36, 37].

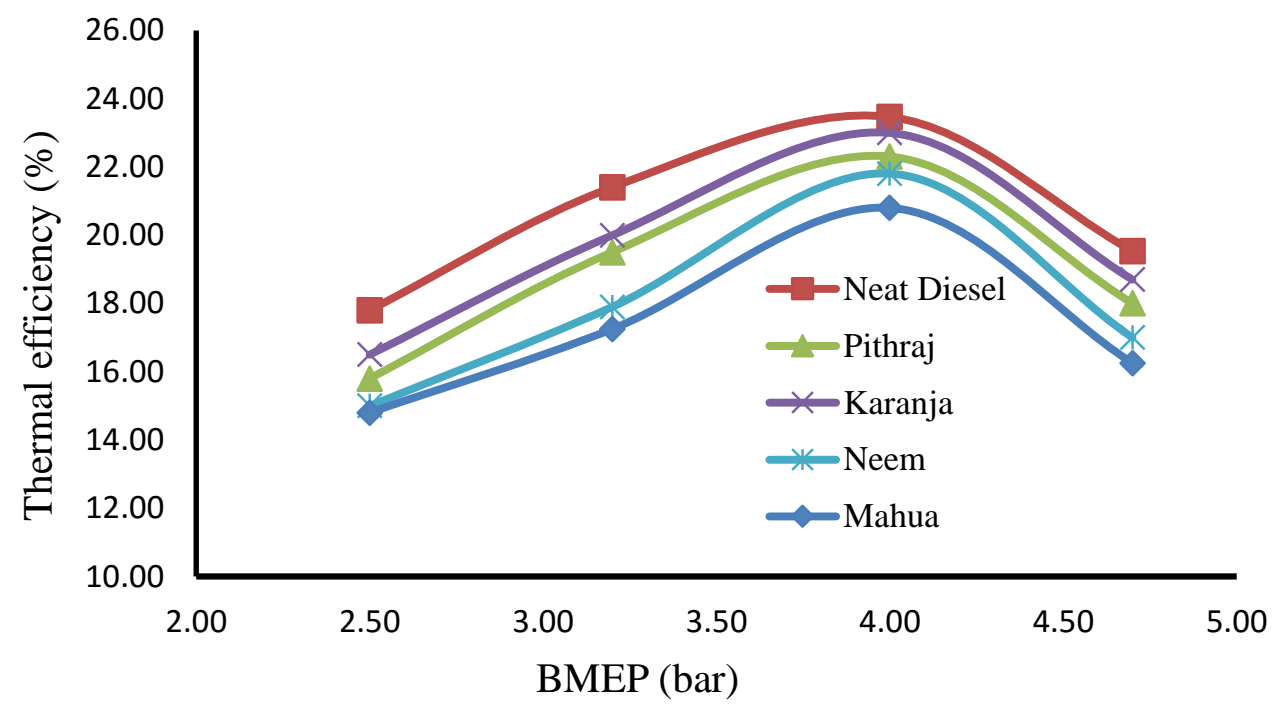

Figure 8 . Thermal efficiency with neat diesel and biodiesel blends.

$\mathrm{NO}_{\mathrm{x}}$ emission characteristics with respect to various BMEP for neat diesel and different biodiesels are illustrated in Figure 9. It is observed from the figure that the $\mathrm{NO}_{\mathrm{x}}$ emission increases with the load as well as with the BMEP for all fuels. This is because $\mathrm{NO}_{\mathrm{x}}$ emission depends mainly on the oxygen concentration, peak temperature, engine dimension, operating condition and fuel injection angle [38,39]. As the load increases for the same amount of air in the cylinder, the fuel consumption is increased. As the $\mathrm{NO}_{\mathrm{x}}$ emission is a function of temperature and it is observed that at the end of the combustion stroke, the temperature of the combustion products rises to around $2600^{\circ} \mathrm{C}$. This rise in temperature causes oxidation of the nitrogen and attributes greatly to $\mathrm{NO}_{\mathrm{x}}$ emission. In contrast, after expansion stroke, the burned gases cool and the $\mathrm{NO}_{\mathrm{x}}$ freezes but the concentration of the $\mathrm{NO}_{\mathrm{x}}$ remains unchanged because the production of $\mathrm{NO}_{\mathrm{x}}$ does not attain the chemical equilibrium reaction state [28]. From Figure 9, it can be seen that the NOx emission of all biodiesel fuels is higher than the neat diesel, and NOx emission by the fuels can be arranged as:

$$
\left(\mathrm{NO}_{\mathrm{x}}\right)_{\text {mahua }}>\left(\mathrm{NO}_{\mathrm{x}}\right)_{\text {neem }}>\left(\mathrm{NO}_{\mathrm{x}}\right)_{\text {pithraj }}>\left(\mathrm{NO}_{\mathrm{x}}\right)_{\text {karanja }}>\left(\mathrm{NO}_{\mathrm{x}}\right)_{\text {neat diesel. }}
$$

This fact can be illustrated by the higher amount of oxygen molecules content by biodiesel fuel than the neat diesel and by keeping the other variables (temperature, engine dimension, operating condition and fuel injection angle) constant for all the fuels that support the former analysis [25]. 


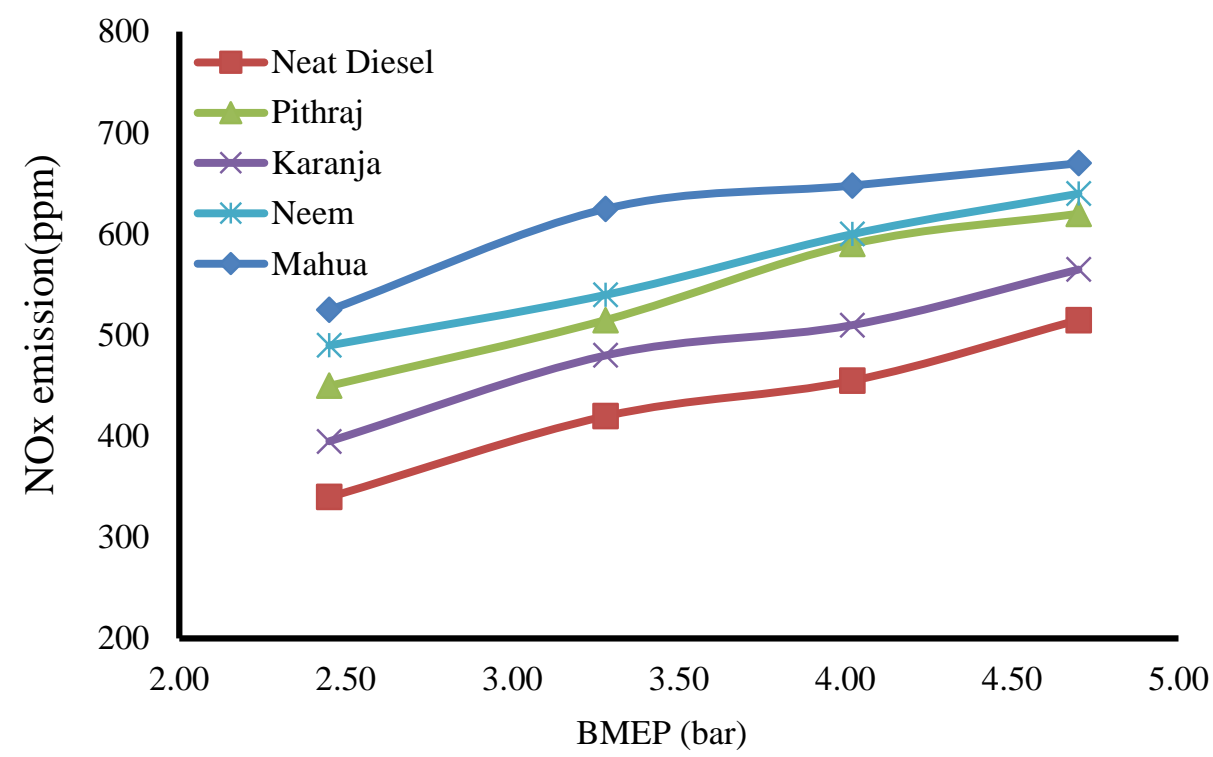

Figure 9. NOx emission with neat diesel and different biodiesels.

Figure 10 demonstrates the variation of $\mathrm{CO}$ emission with the BMEP. It is obvious that the $\mathrm{CO}$ emission increases with the increase in load. As load is increased, the fuel consumption of the fuel by the engine is also increased. Thus, the time available for the complete combustion of the fuel is not available and incomplete combustion takes place. Also, we know,

$$
\begin{aligned}
& \mathrm{C}_{\mathrm{x}} \mathrm{H}_{\mathrm{y}}+\mathrm{O}_{2}=\mathrm{CO}+\mathrm{H}_{2} \mathrm{O} \text { (limited } \mathrm{O}_{2} \text { content) } \\
& \mathrm{C}_{\mathrm{x}} \mathrm{H}_{\mathrm{y}}+\mathrm{O}_{2}=\mathrm{CO}_{2}+\mathrm{H}_{2} \mathrm{O} \text { (excess } \mathrm{O}_{2} \text { content) }
\end{aligned}
$$

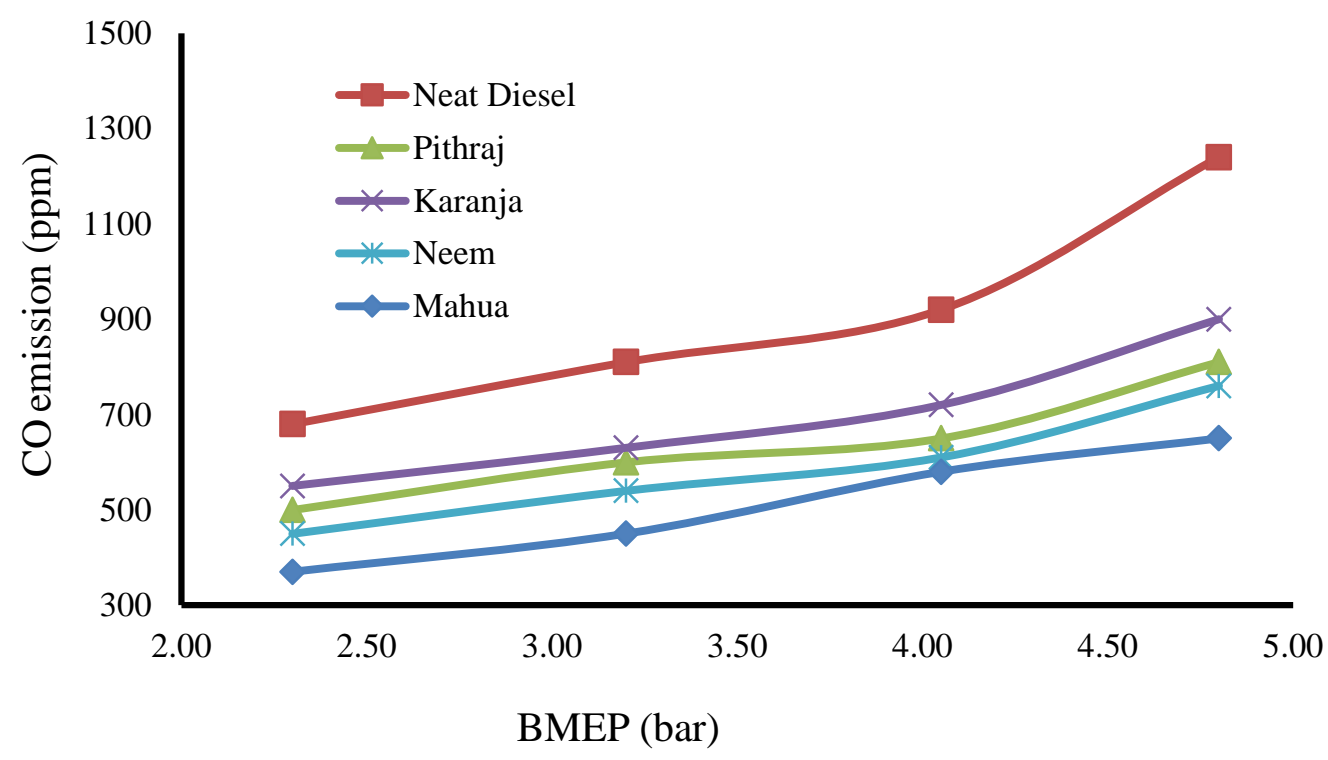

Figure 10. CO emission with neat diesel and different biodiesels.

From the above chemical reaction, it is evident that the $\mathrm{O}_{2}$ content of the fuel is a predominating factor for the $\mathrm{CO}$ emission by the engine. As the load increases, the $\mathrm{A} / \mathrm{F}$ ratio in the engine cylinder becomes richer, which results in a higher $\mathrm{CO}$ emission. But 
biodiesel has a higher $\mathrm{O}_{2}$ than the diesel fuel and thus the A/F ratio becomes leaner. So, the biodiesel emits less $\mathrm{CO}$ than the diesel fuel [40]. At the rated load, diesel fuel produces $27.78 \%, 29.35 \%, 33.7 \%$, and $36.96 \%$ more $\mathrm{CO}$ emission than the karanja, pithraj, neem and mahua biodiesel respectively. Due to the presence of excess $\mathrm{O}_{2}$ molecules in these biodiesels [41], the $\mathrm{CO}$ is further oxidized to produce $\mathrm{CO}_{2}$ and thus results in low $\mathrm{CO}$ emission. Also, there are some other causes behind the $\mathrm{CO}$ emission by the engine, which are characterized by the quality of diesel fuel used, carbon content in bio diesel, combustion temperature, the type of engine, such as standard, turbo or injector, the state of engine tuning, the fuel pump setting, the workload demand on the engine, the engine temperature, and whether the engine has been regularly maintained or not, etc. [42].

\section{CONCLUSIONS}

The experimental work was conducted to produce the biodiesel from the potential inedible feedstocks in Bangladesh which will be a novel alternative to the traditional diesel fuel. In this work, biodiesel was extracted from the karanja (Pongamia pinnata), pithraj (Aphanamixis polystachya), neem (Azadira chtaindica) and mahua (Madhuca longofolia) seed oil. Their properties were compared and details of their performances were investigated. The following conclusions can be drawn for this work:

i. Biodiesel was produced through the transesterification process. The optimum condition for biodiesel production was set close to $22 \mathrm{vol} \%$ of methanol, $0.5 \mathrm{wt} \%$ of $\mathrm{NaOH}$ and $55^{\circ} \mathrm{C}$ reaction temperatures. In this condition, the maximum biodiesel was obtained $96 \%$ for mahua oil, $94 \%$ for neem oil, $92 \%$ for pithraj oil and $91 \%$ for karanja oil. The maximum biodiesel production was determined after 15 hours of reaction time.

ii. The different physiochemical properties of biodiesel were evaluated and compared to the diesel fuel. The experimental data show that the characteristics of all four inedible oil as biodiesel are quite close to neat diesel. The density, viscosity, flash point and fire point are higher for biodiesel fuel, which is not desirable but the cetane number of biodiesel is very promising except for Neem oil.

iii. Brake thermal efficiency of biodiesel was lower than the diesel at the same rated load due to the lower heating value and higher BSFC of the biodiesel.

iv. Compared to the diesel fuel, higher $\mathrm{NO}_{\mathrm{x}}$ and lower $\mathrm{CO}$ emission of the biodiesel was observed. The high content of oxygen in biodiesel fuel is mainly responsible for these facts. The lower $\mathrm{CO}$ emission makes biodiesel fuel environmentally friendly and more attractive. But the $\mathrm{NO}_{\mathrm{x}}$ emission does not solely depend on the oxygen concentration but also to a greater extent, on the fuel injection timing, unsaturated compounds and some other factors. The $\mathrm{NO}_{\mathrm{x}}$ emission can be improved by exhaust gas recirculation to make it a potential alternative source of diesel fuel.

Thus, from the consideration of 3E's (energy, economy and environment), the biodiesel fuel can be a prospective feedstock for Bangladesh, which is also renewable in nature.

\section{ACKNOWLEDGEMENTS}

The authors are indebted to Rajshahi University of Engineering and Technology (RUET) for providing all kinds of support throughout the research work. Grateful acknowledgements are extended to the lab technicians of Heat Engine lab for their help throughout the research work. Authors are also thankful to Mr. Md. Shazib Uddin, Assistant Professor, RUET for his cordial suggestions for the study. 


\section{REFERENCES}

[1] Avinash A, Subramaniam D, Murugesan A. Biodiesel-A global scenario. Renewable and Sustainable Energy Reviews. 2014;29:517-27.

[2] Vashist D, Ahmad M. Statistical analysis of diesel engine performance for castor and jatropha biodiesel-blended fuel. International Journal of Automotive and Mechanical Engineering. 2014;10:2155-69.

[3] Kumaran P, Gopinathan M, Kantharrajan S. Combustion characteristics of improved biodiesel in diffusion burner. International Journal of Automotive and Mechanical Engineering. 2014;10:2112-21.

[4] Khalid A, Jaat N, Sapit A, Razali A, Manshoor B, Zaman I, et al. Performance and emissions characteristics of crude jatropha oil biodiesel blends in a diesel engine. International Journal of Automotive and Mechanical Engineering. 2015;11:2447-57.

[5] Xue J, Grift TE, Hansen AC. Effect of biodiesel on engine performances and emissions. Renewable and Sustainable Energy Reviews. 2011;15:1098-116.

[6] Nabi MN, Hoque SMN, Uddin MS. Production of biodiesel in Bangladesh from inedible renewable pithraj oil and experimental investigation of methyl esters as biodiesel on C.I. engine. International Energy Journal. 2010;11:73-80.

[7] Nabi MN, Hoque SMN, Akhter MS. Karanja (Pongamia Pinnata) biodiesel production in Bangladesh, characterization of karanja biodiesel and its effect on diesel emissions. Fuel Processing Technology. 2009;90:1080-6.

[8] Fukuda H, Kondo A, Noda H. Biodiesel fuel production by transesterification of oils. Journal of bioscience and bioengineering. 2001;92:405-16.

[9] Ma F, Hanna MA. Biodiesel production: a review1. Bioresource Technology. 1999;70:1-15.

[10] Hazar H. Effects of biodiesel on a low heat loss diesel engine. Renewable Energy. 2009;34:1533-7.

[11] Said NH, Ani FN, Said MFM. Review of the production of biodiesel from waste cooking oil using solid catalysts. Journal of Mechanical Engineering and Sciences. 2015;8:1302-11.

[12] Nasir N, Daud Z. Performance of aluminium sulphate and polyaluminium choloride in biodiesel wastewater. Journal of Mechanical Engineering and Sciences. 2014;7:1189-95.

[13] Abdullah NR, Shahruddin NS, Mamat R, Ihsan Mamat AM, Zulkifli A. Effects of air intake pressure on the engine performance, fuel economy and exhaust emissions of a small gasoline engine. Journal of Mechanical Engineering and Sciences. 2014;6:949-58.

[14] Fazal MA, Haseeb ASMA, Masjuki HH. Biodiesel feasibility study: An evaluation of material compatibility; performance; emission and engine durability. Renewable and Sustainable Energy Reviews. 2011;15:1314-24.

[15] Altın R, Çetinkaya S, Yücesu HS. The potential of using vegetable oil fuels as fuel for diesel engines. Energy Conversion and Management. 2001;42:529-38.

[16] Murillo S, Míguez JL, Porteiro J, Granada E, Morán JC. Performance and exhaust emissions in the use of biodiesel in outboard diesel engines. Fuel. 2007;86:176571.

[17] Tullis S, Greeves G. Improving NOx versus BSFC with EUI 200 using EGR and pilot injection for heavy-duty diesel engines. SAE Technical Paper; 1996. 
[18] Hasan MM, Rahman MM, Kadirgama K. A Review on homogeneous charge compression ignition engine performance using biodiesel-diesel blend as a fuel. International Journal of Automotive and Mechanical Engineering. 2015;11:2199211.

[19] Azman SR, Ismail M, Kadhum AAH, Yaakob Z. The performance of monolithic structured calcium oxide for biodiesel. International Journal of Automotive and Mechanical Engineering. 2014;10:1959-70.

[20] Adam IK, A. Aziz AR, Yusup S. Determination of diesel engine performance fueled biodiesel (rubber seed/palm oil mixture) diesel blend. International Journal of Automotive and Mechanical Engineering. 2015;11:2675-85.

[21] Abbaszadeh A, Ghobadian B, Najafi G, Yusaf T. An Experimental investigation of the effective parameters on wet washing of biodiesel purification. International Journal of Automotive and Mechanical Engineering. 2014;9:1525-37.

[22] Nabi M, Hoque S, Uddin M. Prospect of Jatropha curcas and Pithraj cultivation in Bangladesh. J Eng Technol. 2009;7:41-54.

[23] Nabi MN, Hoque SN. Biodiesel production from linseed oil and performance study of a diesel engine with diesel biodiesel. Journal of Mechanical Engineering. 2008;39:40-4.

[24] Puhan S, Vedaraman N, Sankaranarayanan G, Ram BVB. Performance and emission study of Mahua oil (madhuca indica oil) ethyl ester in a 4-stroke natural aspirated direct injection diesel engine. Renewable Energy. 2005;30:1269-78.

[25] Lapuerta M, Armas O, Rodríguez-Fernández J. Effect of biodiesel fuels on diesel engine emissions. Progress in Energy and Combustion Science. 2008;34:198-223.

[26] Dunn R, Bagby M. Low-temperature properties of triglyceride-based diesel fuels: transesterified methyl esters and petroleum middle distillate/ester blends. Journal of the American Oil Chemists' Society. 1995;72:895-904.

[27] Sadeghinezhad E, Kazi SN, Badarudin A, Oon CS, Zubir MNM, Mehrali M. A comprehensive review of biodiesel as alternative fuel for compression ignition engines. Renewable and Sustainable Energy Reviews. 2013;28:410-24.

[28] Srivastava A, Prasad R. Triglycerides-based diesel fuels. Renewable and Sustainable Energy Reviews. 2000;4:111-33.

[29] Fernández CM, Ramos MJ, Pérez Á, Rodríguez JF. Production of biodiesel from winery waste: Extraction, refining and transesterification of grape seed oil. Bioresource Technology. 2010;101:7019-24.

[30] Canakci M, Van Gerpen J. Biodiesel production via acid catalysis. Transactions of the ASAE-American Society of Agricultural Engineers. 1999;42:1203-10.

[31] Berchmans HJ, Hirata S. Biodiesel production from crude Jatropha curcas L. seed oil with a high content of free fatty acids. Bioresource Technology. 2008;99:171621.

[32] Patil K, Thipse S. Characteristics of performance and emissions in a direct injection Diesel engine fuelled with kerosene/diesel Blends. International Journal of Automotive and Mechanical Engineering. 2014;10:2102-11.

[33] Zheng M, Mulenga MC, Reader GT, Wang M, Ting DSK, Tjong J. Biodiesel engine performance and emissions in low temperature combustion. Fuel. 2008;87:714-22.

[34] Carraretto C, Macor A, Mirandola A, Stoppato A, Tonon S. Biodiesel as alternative fuel: Experimental analysis and energetic evaluations. Energy. 2004;29:2195-211. 
[35] Aydin H, Bayindir H. Performance and emission analysis of cottonseed oil methyl ester in a diesel engine. Renewable Energy. 2010;35:588-92.

[36] Yusaf T, Hamawand I, Baker P, Najafi G. The effect of methanol-diesel blended ratio on CI engine performance. International Journal of Automotive and Mechanical Engineering. 2013;8:1385-95.

[37] Yuan W, Hansen AC, Zhang Q. Computational modelling of NOx emissions from biodiesel combustion. International journal of vehicle design. 2007;45:12-32.

[38] Szybist JP, Kirby SR, Boehman AL. NO x emissions of alternative diesel fuels: a comparative analysis of biodiesel and FT diesel. Energy \& fuels. 2005;19:148492.

[39] Ali MH, Mashud M, Rubel MR, Ahmad RH. Biodiesel from neem oil as an alternative fuel for diesel engine. Procedia Engineering. 2013;56:625-30.

[40] Nabi MN, Akhter MS, Zaglul Shahadat MM. Improvement of engine emissions with conventional diesel fuel and diesel-biodiesel blends. Bioresource Technology. 2006;97:372-8.

[41] Anbumani K, Singh AP. Performance of mustard and neem oil blends with diesel fuel in CI engine. Carbon. 2006;86:92.

[42] Shahir VK, Jawahar CP, Suresh PR. Comparative study of diesel and biodiesel on CI engine with emphasis to emissions-A review. Renewable and Sustainable Energy Reviews. 2015;45:686-97.

\section{NOMENCLATURES}

$\mathrm{BD}$

TG

BP

BMEP

BSFC

$\mathrm{CO}_{2}$

$\mathrm{CO}$

$\mathrm{NaOH}$

NA

NOx

PM

rpm
Biodiesel

Tri Glyceride

Brake Power

Brake Mean Effective Pressure

Brake Specific Fuel consumption

Carbon Dioxide

Carbon Monoxide

Sodium Hydroxide

Naturally Aspirated

Nitrogen Oxide

Particulate Matter

Revolution per minute 